\title{
Silver Nanoparticles Alter Cell Adhesion and Proliferation of Sheep Primary Mesothelial Cells
}

\author{
ZOI V. ARSENOPOULOU ${ }^{1}$, IOANNIS A. TAITZOGLOU ${ }^{2}$, PASCHALIS-ADAM MOLYVDAS ${ }^{1}$, \\ KONSTANTINOS I. GOURGOULIANIS ${ }^{3}$, CHRISSI HATZOGLOU ${ }^{1}$ and SOTIRIOS G. ZAROGIANNIS ${ }^{1 *}$ \\ ${ }^{1}$ Department of Physiology, Faculty of Medicine, University of Thessaly, BIOPOLIS, Larissa, Greece; \\ ${ }^{2}$ Laboratory of Physiology, Faculty of Veterinary Medicine, Aristotle University, Thessaloniki, Greece; \\ ${ }^{3}$ Department of Respiratory Medicine, Faculty of Medicine, University of Thessaly, BIOPOLIS, Larissa, Greece
}

\begin{abstract}
Background: Human exposure to engineered nanoparticles has been linked to pleural effusion, inflammation and fibrosis. Silver nanoparticles (AgNPs) are widely used in medical and domestic products, increasing the risk of occupational and domestic exposure. We assessed the influence of AgNPs on adhesion and proliferation of sheep primary pleural mesothelial cells. Materials and Methods: Cells were used for cell adhesion $(90 \mathrm{~min})$ and proliferation experiments (3 days) while exposed to $20 \mathrm{~nm}$ and $60 \mathrm{~nm}$ AgNPs $(0.2 \mu \mathrm{g} / \mathrm{ml}$ and $2 \mu \mathrm{g} / \mathrm{ml})$ using colorimetric assays. Results: Exposure to $0.2 \mu \mathrm{g} / \mathrm{ml}$ of $20 \mathrm{~nm}$ and $60 \mathrm{~nm}$ AgNPs significantly increased cell adhesion, while at $2 \mu \mathrm{g} / \mathrm{ml}$ this effect was not elicited. Cell proliferation was significantly increased by both $20 \mathrm{~nm}$ and $60 \mathrm{~nm}$ AgNPs at $0.2 \mu \mathrm{g} / \mathrm{ml}$, while at $2 \mu \mathrm{g} / \mathrm{ml}$ this effect was only elicited by the $60 \mathrm{~nm}$ AgNPs. Conclusion: AgNPs alter the adhesive and proliferative properties of primary pleural mesothelial cells.
\end{abstract}

Exposure to engineered nanoparticles (NPs) may damage the lungs and the pleura inducing inflammation, fibrosis and cancer (1). Mouse studies showed that inhaled carbon nanotubes reach the sub-pleural tissue and promote pleural inflammation and fibrosis, while direct intrapleural injection of carbon nanotubes leads to pleural inflammation and progressive fibrosis of the parietal pleura $(2,3)$. These results suggest that NPs can exert asbestos-like detrimental effects,

This article is freely accessible online.

Correspondence to: Sotirios G. Zarogiannis, Ph.D., MPH, Environmental Pleural \& Lung Diseases Group, Department of Physiology, Faculty of Medicine, University of Thessaly, 3 Panepistimiou Str., BIOPOLIS, Larissa 41500, Greece. Tel: +30 2410685558, Fax: +30 2410685555, e-mail: szarog@med.uth.gr

Key Words: Cell adhesion, cell proliferation, mesothelial, pleura, silver nanoparticles. with similar pathogenic manifestations and risk for mesothelioma development (4).

There are already a few clinical reports regarding NPinduced pleural pathology. A case series showed that inhalation exposure of factory workers to polyacrylate/ nanosilica NPs resulted in pleural effusion and foreign body granulomas (5). A subsequent analysis of pleural fluid samples from the exposed workers further strengthened the notion that exposure to NPs promotes pleural effusion development, since polyacrylate/nanosilica NPs were detected in their pleural fluid and corresponding lung biopsies (6).

Based on the above, studies on silver nanoparticles (AgNPs) in the pleura are of particular interest for two reasons. Firstly, they are vastly produced and used in a large number of consumer products and medical devices, thus, increasing the probability of occupational and consumer exposure (7). A mouse study evaluating the pleural effects of AgNPs showed that a single intrapleural injection of silver nanofibers promoted acute pleural inflammation and subsequent fibrosis when their length was beyond $4 \mu \mathrm{m}(8)$. We previously reported that ex vivo exposure of sheep pleura to spherical AgNPs of 20 and $60 \mathrm{~nm}(2 \mu \mathrm{g} / \mathrm{ml})$ increased membrane permeability after $30 \mathrm{~min}$ of pre-incubation, while longer in vitro exposure $(24 \mathrm{~h})$ had the opposite effects, reducing the permeability of monolayers of sheep primary pleural mesothelial cells (9). Secondly, silver nitrate is an agent that has been clinically used to induce chemical pleurodesis in patients with malignant pleural effusions and therefore silver can exert toxic effects on the pleura by inducing inflammation and fibrosis, especially when given in low doses (10). In animal studies, it has been described that after silver nitrate-induced injury, focal re-mesothelialization occurs (11). Therefore, mesothelial cell functions such as cell adhesion and proliferation are pivotal for the repair of such an injury. Thus, the scope of the current report was to assess the in vitro effects of AgNPs on adhesion and proliferation of sheep primary mesothelial cells. 


\section{Materials and Methods}

Nanoparticle treatments. AgNPs of 20 and $60 \mathrm{~nm}$ in diameter (\#730793 and 730815 respectively) were obtained from Sigma-Aldrich, Darmstadt, Germany. They were monodisperse, spherical and stabilized in aqueous sodium citrate solution. Prior to experiment, AgNPs were vortexed for $5 \mathrm{~min}$ and re-suspended at final concentrations of 0.2 $\mu \mathrm{g} / \mathrm{ml}$ or $2 \mu \mathrm{g} / \mathrm{ml}$ in $10 \%$ fetal bovine serum (FBS)-RPMI cell culture medium. The corresponding controls were aqueous solutions of 0.02 $\mathrm{mM}$ or $0.2 \mathrm{mM}$ sodium citrate in RPMI medium. Plastic cell culture surfaces were treated for $30 \mathrm{~min}$ with fibronectin (FN) solution (50 $\mu \mathrm{g} / \mathrm{ml}$; Calbiochem, San Diego, CA, USA).

Cell culture. Sheep primary pleural mesothelial cells were isolated from specimens of intact visceral sheep pleura obtained from the local slaughterhouse immediately after the death of the animal. Pieces of approximately $2 \mathrm{~cm}^{2}$ were washed with phosphatebuffered saline (PBS) and transported to the laboratory in 10\% FBSRPMI medium supplemented with $5 \%$ antibiotics and $1 \% \mathrm{~L}$ glutamine. They were placed in sterile FN-coated petri dishes on top of five areas where the plastic was incised with a scalpel and filled with $3 \mathrm{ml}$ of $10 \%$ FBS-RPMI medium (supplemented with $1 \%$ penicillin/streptomycin and $1 \% \mathrm{~L}$-glutamine) and placed in a humidified incubator $\left(37^{\circ} \mathrm{C}\right.$ and $\left.5 \% \mathrm{CO}_{2}\right)$. Cell medium was changed the next day and then every third day. Pleural specimens were discarded after 6 days.

Cell adhesion assay. For cell adhesion experiments, sheep primary pleural mesothelial cells were serum starved (0.5\% FBS-RPMI medium) for $24 \mathrm{~h}$, harvested and re-suspended in RPMI medium with $20 \mathrm{~nm}$ or $60 \mathrm{~nm}$ AgNPs at $0.2 \mu \mathrm{g} / \mathrm{ml}$ and $2 \mu \mathrm{g} / \mathrm{ml}$ concentrations. Cells were seeded in FN-coated 48 -well plates $\left(2.5 \times 10^{4}\right.$ cells/well $)$, and allowed to adhere for $3 \mathrm{~h}$ at $37^{\circ} \mathrm{C}$ in a humidified incubator with $5 \% \mathrm{CO}_{2}$. After a warm PBS wash for removal of unattached cells, adherent cells were fixed with $4 \%$ paraformaldehyde, stained with $0.5 \%$ crystal violet for $15 \mathrm{~min}$ and subsequently the stain was aspirated followed by washing the plate in running tap water. The stain was then extracted by 20 min incubation with $10 \%$ acetic acid and the optical density (OD) was measured at $570 \mathrm{~nm}$. The experiment was repeated twice with six replicates.

Cell proliferation assay. For cell proliferation experiments, sheep primary pleural mesothelial cells were serum starved (0.5\% FBSRPMI medium) for 24 hours, harvested and re-suspended in RPMI medium with $20 \mathrm{~nm}$ or $60 \mathrm{~nm} \mathrm{AgNPs}$ at $0.2 \mu \mathrm{g} / \mathrm{ml}$ and $2 \mu \mathrm{g} / \mathrm{ml}$ concentrations. Cells were plated on FN-coated 96 well-plates $\left(10^{4}\right.$ cells/well). Proliferation was examined at days 0,1,2 and 3 after seeding. At each time point the medium was removed; cells were washed with PBS and fixed with $4 \%$ paraformaldehyde followed by staining with $0.5 \%$ crystal violet for $15 \mathrm{~min}$. The stain was then aspirated and the plates were washed with running tap water and dried overnight. Subsequently, they were de-stained with $10 \%$ acetic acid and the number of proliferating cells was quantitatively reflected by O.D. values measured at $570 \mathrm{~nm}$ by spectrophotometry. The experiment was repeated twice with six replicates.

Statistical analyses. Statistical analysis was performed using GraphPad Prism 7, La Jolla, CA, USA. Data are expressed as the mean \pm S.E.M. One-way ANOVA with Tukey's multiple comparisons test or two-way ANOVA with Bonferroni post-test was used where appropriate. Values of $p<0.05$ were deemed significant.

\section{Results}

Exposure of sheep primary pleural mesothelial cells to $0.2 \mu \mathrm{g} / \mathrm{ml} 20 \mathrm{~nm}$ and $60 \mathrm{~nm}$ AgNPs increased cell adhesion compared to controls ( $p<0.05$ and $p<0.001$, respectively). The effect was more pronounced in the group treated with $60 \mathrm{~nm}$ AgNPs compared to the $20 \mathrm{~nm}$ AgNPs group (Figure $1 \mathrm{~A} ; p<0.01)$. Contrary to these results, when sheep primary pleural mesothelial cells were exposed to $2 \mu \mathrm{g} / \mathrm{ml}$ of $20 \mathrm{~nm}$ or $60 \mathrm{~nm}$ AgNPs, no significant differences were observed (Figure 1B).

In cell proliferation experiments, $20 \mathrm{~nm} \mathrm{AgNPs}$ at a concentration of $0.2 \mu \mathrm{g} / \mathrm{ml}$ significantly increased cell proliferation on days 2 and 3 compared to controls $(p<0.001$ in both days), while $60 \mathrm{~nm} \mathrm{AgNPs} \mathrm{significantly} \mathrm{increased}$ cell proliferation from day $1(p<0.05)$ through days 2 and 3 $(p<0.001$ both days). Finally, there was a significant difference $(p<0.05)$ between the effect on cell proliferation of cells exposed to $60 \mathrm{~nm}$ AgNPs, which was higher compared to AgNPs of $20 \mathrm{~nm}$ (Figure 2A). The higher concentration of AgNPs $(2 \mu \mathrm{g} / \mathrm{ml})$ significantly increased cell proliferation only of cells treated with $60 \mathrm{~nm} \mathrm{AgNPs.} \mathrm{As}$ shown in Figure 2B, at days 2 and 3 , there was significantly higher cell proliferation of cells exposed to $60 \mathrm{~nm} \mathrm{AgNPs} \mathrm{as}$ compared both to controls ( $p<0.001$ in both days) and cells treated with $20 \mathrm{~nm} \mathrm{AgNPs} \mathrm{(} p<0.001$ both days).

\section{Discussion}

AgNPs have unique properties that render them suitable for broad use in medical and consumer applications and therefore they are intensely investigated for potential health-related hazards. In this study, we investigated the effects of AgNPs on the adhesive and proliferative properties of sheep primary pleural mesothelial cells. Inhalation exposure of humans to around $30 \mathrm{~nm}$ polyacrylate/silica NPs has provided evidence that they reach the pleural space and can promote inflammation and fibrosis $(5,6)$. Currently, as far as we are aware of, no studies on the effects of AgNPs on mesothelial cell adhesion and proliferation are available to compare our results with. A study similar to ours, showed that exposure to high concentrations $(100 \mu \mathrm{g} / \mathrm{ml})$ of titanium dioxide NPs reduced adhesion of $\mathrm{H} 441$ cells (Clara-like cells) to $\mathrm{FN}$, while lower concentrations $(10 \mu \mathrm{g} / \mathrm{ml})$ had no effect (12). In our study, we used 50- and 5-fold lower concentrations, finding increased adhesion at $0.2 \mu \mathrm{g} / \mathrm{ml}$ and no effects at $2 \mu \mathrm{g} / \mathrm{ml}$. AgNPs have been described to have hormetic effects (i.e. opposite effects of the same NP at low and high concentrations) and this, as well as the different nature of NPs used in the two studies, could explain the differences in cell adhesion mentioned above (13). In addition, one should take into account that different types of NPs may have completely different effects at the same sizes and concentrations (14). 

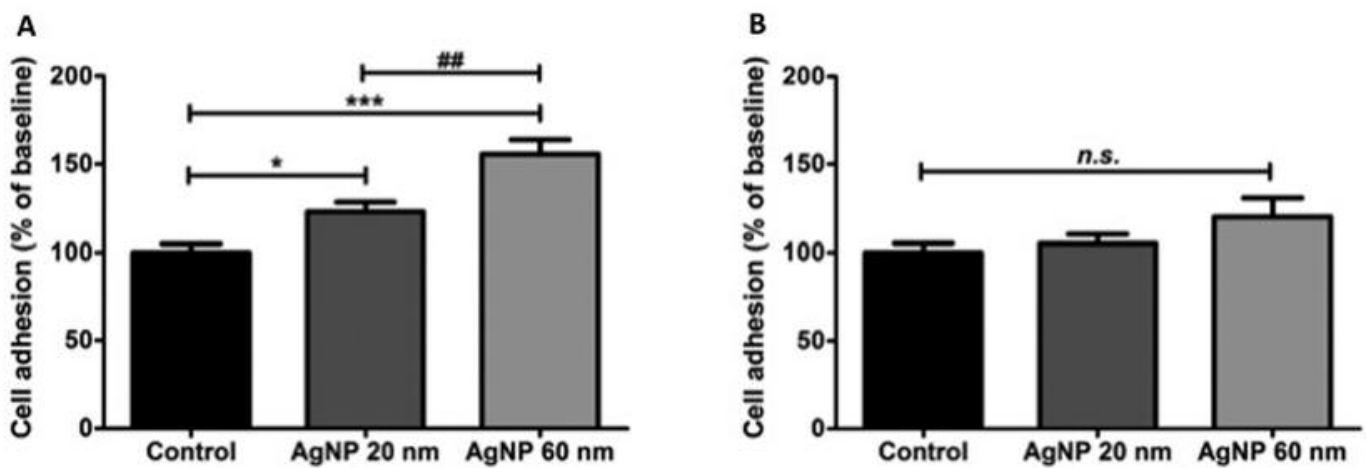

Figure 1. Cell adhesion (mean $\pm S E M)$ of sheep primary pleural mesothelial cells after exposure to silver nanoparticles (AgNP). Cells were exposed to $0.02 \mathrm{mM}$ sodium citrate (Control; $n=12$ ), or $0.2 \mu \mathrm{g} / \mathrm{ml}(A)$ or $2 \mu \mathrm{g} / \mathrm{ml}(B) A g N P s$ of $20 \mathrm{~nm}(\mathrm{n=12})$ and $60 \mathrm{~nm}(\mathrm{n}=12)$ for $3 \mathrm{~h}$ then cell adhesion

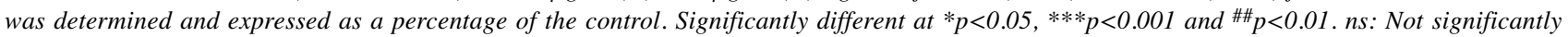
different.
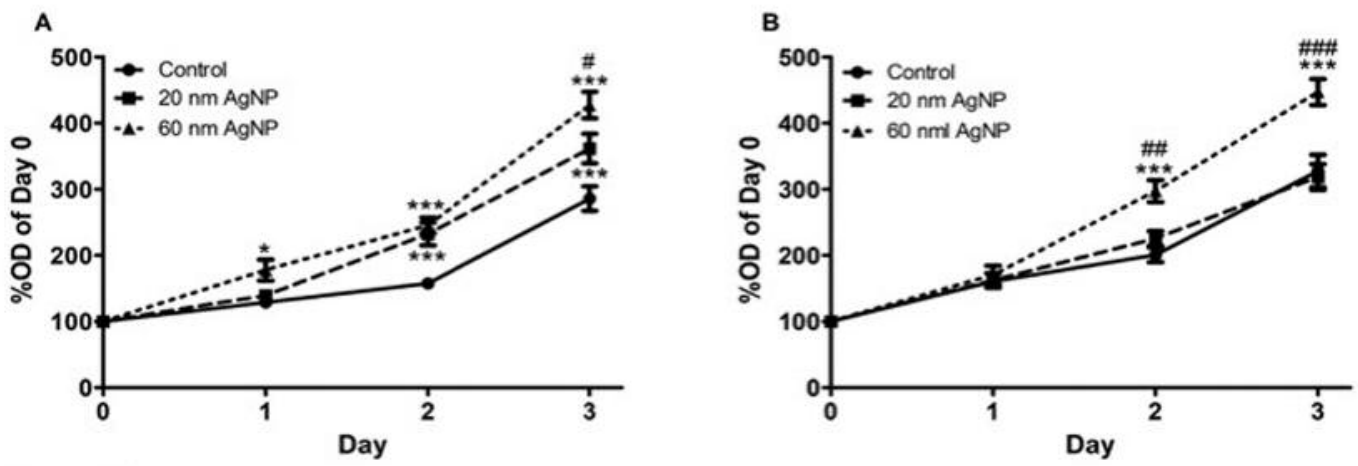

Figure 2. Cell proliferation of sheep primary pleural mesothelial cells was assessed for 3 days after exposure to $0.02 \mathrm{mM}$ sodium citrate (Control; $n=15)$, or $0.2 \mu \mathrm{g} / \mathrm{ml}(\mathrm{n=15})$ (A) or $2 \mu \mathrm{g} / \mathrm{ml}$ (B) AgNPs of $20 \mathrm{~nm}$ and $60 \mathrm{~nm}(\mathrm{n}=15)$. Cells were stained with crystal violet and the optical density $(O D)$ of the extracted dye measured. Significantly different at $* p<0.05$ and $* * * p<0.001$ comparison versus control, and ${ }^{\#} p<0.05$ and $\# \# \#<0.001$ versus $20 \mathrm{~nm}$ AgNPs (B).

Our findings could be due to NP-mediated disruption of the microtubule network resulting in stronger substrate adhesion, a mechanism described in oral mucosa cells exposed to silica, titanium and hydroxyapatite NPs (15).

An increase in cell proliferation after exposure to AgNPs has been described in primary cultures of rat coronary endothelial cells where $45 \mathrm{~nm}$ AgNPs were shown to have dual effects (16). More specifically, low concentrations of AgNPs ranging from 1.0 to $10 \mu \mathrm{g} / \mathrm{ml}$ inhibited cell proliferation, while concentrations of 50 to $100 \mu \mathrm{g} / \mathrm{ml}$ increased it. This is another example of hormetic effects caused by exposure to AgNPs $(13,16)$. In our study, AgNPs of $20 \mathrm{~nm}$ stimulated sheep primary pleural mesothelial cell proliferation only at very low concentrations $(0.2 \mu \mathrm{g} / \mathrm{ml})$, while $60 \mathrm{~nm}$ AgNPS stimulated proliferation at both concentrations tested. On the other hand, several studies on various benign and malignant cell lines have reported antiproliferative effects of AgNPs that are more prominent with small size NPs $(17,18)$. We previously showed that the effects of AgNPs on the permeability properties of sheep primary pleural mesothelial cell monolayers are significantly more pronounced compared to a human pleural mesothelial cell line monolayer, suggestive of the notion that results obtained from primary cell cultures and cell lines may be significantly different under the same experimental conditions (9). Overall it is important to note that spherical metallic NPs, such as the ones we used in our study, can pass rapidly into the circulation and therefore low concentration like those we used in our study would be of clinical relevance (19).

In summary, we showed that at low concentrations $(0.2 \mu \mathrm{g} / \mathrm{ml}) 20 \mathrm{~nm}$ and $60 \mathrm{~nm}$ AgNPs increased cell adhesion and proliferation of sheep primary pleural mesothelial cells, 
with $60 \mathrm{~nm}$ AgNPs having more pronounced effects. At higher concentration $(2 \mu \mathrm{g} / \mathrm{ml}), 20$ and $60 \mathrm{~nm}$ AgNPs had no effect on cell adhesion and only the $60 \mathrm{~nm}$ AgNPs significantly increased cell proliferation. Inhaled NPs can reach the pleural space and therefore the pathophysiological significance of our findings should be further investigated.

\section{Acknowledgements}

Z.V. Arsenopoulou is recipient of an IKY Fellowship of Excellence for Postgraduate Studies in Greece - Siemens Program.

\section{References}

1 Donaldson $\mathrm{K}$ and Poland CA: Inhaled nanoparticles and lung cancer - what we can learn from conventional particle toxicology. Swiss Med Wkly 142: 13547, 2012.

2 Ryman-Rasmussen JP, Cesta MF, Brody AR, Shipley-Phillips JK, Everitt JI, Tewksbury EW, Moss OR, Wong BA, Dodd DE, Andersen ME and Bonner JC: Inhaled carbon nanotubes reach the subpleural tissue in mice. Nat Nanotechnol 4: 747-751, 2009.

3 Murphy FA, Poland CA, Duffin R, Al-Jamal KT, Ali-Boucetta H, Nunes A, Byrne F, Prina-Mello A, Volkov Y, Li S, Mather SJ, Bianco A, Prato M, Macnee W, Wallace WA, Kostarelos K and Donaldson K: Length-dependent retention of carbon nanotubes in the pleural space of mice initiates sustained inflammation and progressive fibrosis on the parietal pleura. Am J Pathol 178: 2587-2600, 2011.

4 Jaurand MC, Renier A and Daubriac J: Mesothelioma: Do asbestos and carbon nanotubes pose the same health risk? Part Fibre Toxicol 6: 16, 2009.

5 Song Y, Li X and Du X: Exposure to nanoparticles is related to pleural effusion, pulmonary fibrosis and granuloma. Eur Respir J 34: 559-567, 2009.

6 Song Y, Li X, Wang L, Rojanasakul Y, Castranova V, Li H and Ma J: Nanomaterials in humans: identification, characteristics, and potential damage. Toxicol Pathol 39: 841-849, 2011.

7 Martínez-Gutiérrez F, Guajardo-Pacheco JM, Noriega-Trevino ME, Thi EP, Reiner N, Orrantia E, Av-Gay Y, Ruiz F and Bach $\mathrm{H}$ : Antimicrobial activity, cytotoxicity and inflammatory response of novel plastics embedded with silver nanoparticles. Future Microbiol 8: 403-411, 2013.

8 Schinwald A, Murphy FA, Prina-Mello A, Poland CA, Byrne F, Movia D, Glass JR, Dickerson JC, Schultz DA, Jeffree CE, Macnee $\mathrm{W}$ and Donaldson K: The Threshold length for fiberinduced acute pleural inflammation: shedding light on the early events in asbestos-induced mesothelioma. Toxicol Sci 128: 461$470,2012$.
9 Arsenopoulou ZV, Taitzoglou IA, Molyvdas PA, Gourgoulianis KI, Hatzoglou C and Zarogiannis SG: Silver nanoparticles alter the permeability of sheep pleura and of sheep and human pleural mesothelial cell monolayers. Environ Toxicol Pharmacol 50: 212-215, 2017.

10 Marchi E, Vargas FS, Teixeira LR, Acencio MM, Antonangelo L and Light RW: Intrapleural low-dose silver nitrate elicits more pleural inflammation and less systemic inflammation than lowdose talc. Chest 128: 1798-1804, 2005.

11 Genofre EH, Vargas FS, Antonangelo L, Teixeira LR, Vaz MA, Marchi E and Capelozzi VL: Ultrastructural acute features of active remodeling after chemical pleurodesis induced by silver nitrate or talc. Lung 183: 197-207, 2005.

12 Zarogiannis SG, Filippidis AS, Fernandez S, Jurkuvenaite A, Ambalavanan N, Stanishevsky A, Vohra YK and Matalon S: Nano- $\mathrm{TiO}_{2}$ particles impair adhesion of airway epithelial cells to fibronectin. Respir Physiol Neurobiol 185: 454-460, 2013.

13 Jiao ZH, Li M, Feng YX, Shi JC, Zhang J and Shao B: Hormesis effects of silver nanoparticles at non-cytotoxic doses to human hepatoma cells. PLoS One 9: e102564, 2014.

14 Williams KM, Gokulan K, Cerniglia CE and Khare S: Size and dose dependent effects of silver nanoparticle exposure on intestinal permeability in an in vitro model of the human gut epithelium. J Nanobiotechnology 14: 62, 2016.

15 Tay CY, Cai P, Setyawati MI, Fang W, Tan LP, Hong CH, Chen $\mathrm{X}$ and Leong DT: Nanoparticles strengthen intracellular tension and retard cellular migration. Nano Lett 14: 83-88, 2014.

16 Rosas-Hernández H, Jiménez-Badillo S, Martínez-Cuevas PP, Gracia-Espino E, Terrones H, Terrones M, Hussain SM, Ali SF and González C: Effects of 45-nm silver nanoparticles on coronary endothelial cells and isolated rat aortic rings. Toxicol Lett 191: 305-313, 2009.

17 McCracken C, Zane A, Knight DA, Hommel E, Dutta PK and Waldman WJ: Oxidative stress-mediated inhibition of intestinal epithelial cell proliferation by silver nanoparticles. Toxicol In Vitro 29: 1793-1808, 2015.

18 Park MV, Neigh AM, Vermeulen JP, de la Fonteyne LJ, Verharen HW, Briedé JJ, van Loveren $\mathrm{H}$ and de Jong WH: The effect of particle size on the cytotoxicity, inflammation, developmental toxicity and genotoxicity of silver nanoparticles. Biomaterials 32: 9810-9817, 2011.

19 Buzea C, Pacheco II and Robbie K: Nanomaterials and nanoparticles: sources and toxicity. Biointerphases 2: MR17-71, 2007. 